\title{
Antimicrobial applications of nanotechnology: methods and literature
}

\author{
This article was published in the following Dove Press journal: \\ International Journal of Nanomedicine \\ 5 June 2012 \\ Number of times this article has been viewed
}

\section{Justin T Seil \\ Thomas J Webster}

Laboratory for Nanomedicine Research, School of Engineering, Brown University, Providence, RI, USA
Correspondence: Thomas J Webster School of Engineering, Brown University, Box D, 182 Hope Street,

Providence, RI 02917, USA

Tel +I 40I 8632677

Fax +I 40I 8632676

Email thomas_webster@brown.edu

\begin{abstract}
The need for novel antibiotics comes from the relatively high incidence of bacterial infection and the growing resistance of bacteria to conventional antibiotics. Consequently, new methods for reducing bacteria activity (and associated infections) are badly needed. Nanotechnology, the use of materials with dimensions on the atomic or molecular scale, has become increasingly utilized for medical applications and is of great interest as an approach to killing or reducing the activity of numerous microorganisms. While some natural antibacterial materials, such as zinc and silver, possess greater antibacterial properties as particle size is reduced into the nanometer regime (due to the increased surface to volume ratio of a given mass of particles), the physical structure of a nanoparticle itself and the way in which it interacts with and penetrates into bacteria appears to also provide unique bactericidal mechanisms. A variety of techniques to evaluate bacteria viability, each with unique advantages and disadvantages, has been established and must be understood in order to determine the effectiveness of nanoparticles (diameter $\leq 100 \mathrm{~nm}$ ) as antimicrobial agents. In addition to addressing those techniques, a review of select literature and a summary of bacteriostatic and bactericidal mechanisms are covered in this manuscript.
\end{abstract}

Keywords: nanomaterial, nanoparticle, nanotechnology, bacteria, antibacterial, biofilm

\section{The need for novel antibiotics}

In recent years, the number of infections associated with antibiotic-resistant bacteria has increased. The Center for Disease Control and Prevention reports that the number of annual multidrug-resistant Staphylococcus aureus (MRSA) infections increased from 127,000 to 278,000 between the years 1999 and 2005. Similarly, the number of annual MRSA-related deaths increased from 11,000 to 17,000 over the same time frame. While a decline in the prevalence of MRSA infections was reported from 2005 to 2008 due to the implementation of preventative measures, ${ }^{1}$ these infections remain a concern. The rise of MRSA is attributed primarily to the overuse and improper use of antibiotics. Bacteria, with their large populations and fast reproduction time, are able to rapidly develop mechanisms of antibiotic resistance when a subset of the bacteria population survives antibiotic exposure. Antibiotic resistance may develop via multiple mechanisms. Briefly, the primary mechanisms include alteration or inactivation of the antibiotic by the bacteria, alteration of the target site of the antibiotic, alteration of a metabolic pathway to avoid the disruptive effect of the antibiotic, and reduced accumulation of the drug by minimizing its entry or maximizing clearance from the cell. To illustrate one such mechanism, inactivation of the antibiotic, antibiotic resistance may be due to the ability of the bacteria to adapt production of beta-lactamase 
enzymes which cleave the beta-lactam ring, neutralizing beta-lactam antibiotics such as penicillin. Bacteria, such as $S$. aureus, may use this mechanism alone, or in conjunction with other resistance mechanisms, to dramatically reduce its susceptibility to the bactericidal effects of large classes of traditional antibiotics. For this reason, entirely new approaches to antibiotic development are necessary to keep up with the constantly changing antibiotic resistance of bacteria. Nanoparticles, which rely on entirely different mechanisms of antibacterial activity than traditional antibiotics, provide a compelling alternative.

\section{Assays to evaluate antibacterial activity}

Determining the effectiveness of a nanoparticle as an antibacterial agent requires experimental techniques that measure bacteria viability after exposure. While numerous techniques have been developed to determine the antibacterial activity of nanoparticles, many of them are flawed in their own way. As a result, multiple techniques are often used in a single study to compare and confirm antibacterial results. Furthermore, Gram-positive and Gram-negative bacteria may respond to antibacterial nanoparticles differently and also assay differently. Therefore, studies often include at least one Gram-positive species and one Gram-negative species in a variety of assays to determine antibiotic efficacy. Due to the importance of developing novel antibacterial treatments, this paper will summarize current assays used for assessing in vitro bacteria activity, highlighting advantages and disadvantages of each assay (Table 1). The technique chosen for a study depends, in part, on the type of data needed. Bacteria plating is a technique that can be used to evaluate bacteria susceptibility to nanoparticles. This assay is a simple way to identify whether the experimental conditions produced an entirely antibacterial environment, and thus this assay determines minimum inhibitory concentrations (MIC) or minimum bactericidal concentrations (MBC). Other more sophisticated assays, including live/dead staining and tetrazolium salt reduction assays provide data related to specific percentages of bacteria viability in the presence of the antibacterial agent.

\section{Optical density of cell suspensions}

Cell density in a planktonic bacteria suspension is often estimated by measuring the optical density, or turbidity, of the cell suspension and correlating that optical density to cell concentration. Using this technique, the rate of proliferation can be estimated by measuring cell density across a range of time points. As bacteria proliferate in cell culture media, their cell bodies increasingly block light that passes through the sample. The optical density of samples of a standard volume (and associated light path length) can be measured with a spectrophotometer and compared to other samples. When less light is able to penetrate a sample, the density of bacteria in the sample is greater. While some studies report values from direct optical density measurements, others establish a standard curve so that experimental optical density values can be matched with cell density. This cell density is often established by serially diluting a bacteria cell suspension, measuring the optical density of the dilutions, and then spreading each sample onto an agar plate. After an appropriate incubation time, the bacteria colonies can be counted to more accurately determine the number of colony forming units (CFUs) present in each sample.

While the advantage of optical density measurements is its simplicity (no reagents or processing of the sample is required), one complication associated with using optical density techniques to determine bacteria viability in the presence of nanoparticles is that nanoparticles themselves contribute to the optical density of the sample. Like bacteria

Table I Comparison of commonly-used methods of quantifying bacteria viability

\begin{tabular}{lll}
\hline Assay & Advantages & Disadvantages \\
\hline $\begin{array}{l}\text { Optical density measurement } \\
\text { Cell counting devices }\end{array}$ & Quick, no reagents required & Spectrophotometer required, low accuracy \\
Spread-plate (colony counts on agar) & High accuracy & Costly device \\
& & Determines CFU count but not total cell population or \\
& & size of CFUs, time consuming, large amounts of disposable \\
& materials required, cells must be removed from surfaces for & measurement \\
Crystal violet staining & Quantifies biofilm formation & Spectrophotometer required, not suitable for planktonic \\
& & bacteria growth \\
Live/dead fluorescent stain & Allows visualization of sample surface & Costly reagents, fluorescent plate reader or microscope required \\
MTS/MTT/XTT assays & Measures cell viability on surfaces and & Spectrophotometer required, costly reagents \\
& in solution &
\end{tabular}

Abbreviation: CFU, colony forming unit. 
cell bodies, nanoparticles are also capable of scattering spectrophotometer light. To resolve this issue, authors of some studies have measured the optical densities of a standard curve of nanoparticles alone and then subtracted those values from the optical densities of the suspensions of a combination of cells and nanoparticles. ${ }^{2}$ However, the precision with which cell density can be measured with this technique, particularly at low cell densities, is questionable.

\section{Cell counting instruments}

Devices used to quantify the number of cells in a liquid suspension, including Coulter counters, can also be used to determine bacteria populations. A Coulter counter operates by drawing a cell suspension through a channel that separates two chambers of an electrolyte solution. Interference with the conductivity between two chambers of the electrolyte solution, due to the resistance of the cells, is detected and processed to determine cell density. The presence of cells (as well as other particles) and the size distribution of the cells (or size of a CFU of bacteria) can be determined.

In contrast to optical density measurements which do not provide information on the size of the cells and particles present, a Coulter counter provides more useable data. Issues related to nanoparticle interference with cell counting are avoided.

\section{Spread-plate colony counts}

Viable CFUs present after exposure to nanoparticles can also be determined by spreading bacteria suspensions on an agar plate. In the so called spread-plate technique, cell suspension samples are serially diluted and a small volume of sample is then spread across the surface of an agar plate (often with a Lazy-L Spreader ${ }^{\mathrm{TM}}$ [Sigma Aldrich Corp, St Louis, MO] or similar device). CFUs are counted after an incubation period. Taking the dilution process into consideration, calculations are then performed to determine the cell density in the original sample. When compared to plates spread from samples that did not contain nanoparticles, the percent reduction in viable CFUs can be determined.

A CFU counted on an agar plate may have arisen from a single bacterium or may have come from a larger cluster of many bacteria. Uncertainty in the experimental results can arise when an additive to a bacteria cell suspension that reduces the yield of CFUs may be killing a portion of the bacteria, or may only be causing the bacteria to flocculate. This uncertainty makes use of multiple techniques to confirm results additionally important. In some cases, low intensity ultrasound treatment may be used to disrupt bacteria clusters into individual cells, thus, increasing the number of CFUs and providing data that more accurately relates to the total number of viable cells present.

One critique of the accuracy of evaluating the antibacterial effect of nanoparticles in a liquid system is that as nanoparticles interact with intracellular components of lysed cells, nanoparticle agglomeration occurs and prevents nanoparticle interactions with still living cells. ${ }^{3}$ The incorporation of nanoparticles directly into a nutrient agar surface ensures exposure to the bacteria on the surface of the plate, but reduces complications associated with the nanoparticles being "thrown out" of the liquid system. In many studies, nanoparticles are incorporated directly into the agar plate rather than a liquid media suspension. A small volume of bacteria suspension is spread on the agar plate and incubated. CFUs are counted after suitable colony development. A reduced number of CFUs on an agar plate with incorporated nanoparticles indicates that the nanoparticles have an antibacterial effect.

\section{Crystal violet staining}

As a bacteria colony takes hold in a host, a biofilm may be formed. Crystal violet (hexamethyl pararosaniline chloride) can be used to evaluate the amount of biofilm formed by staining the thick peptidoglycan layer of Gram-positive bacteria, the thin peptidoglycan layer of Gram-negative bacteria, and components of the extracellular biofilm. ${ }^{4}$ When exposed to a crystal violet stain solution, the amount of stain absorbed by the biofilm is generally proportional to the quantity of biofilm present. A standardized rinsing procedure can remove the unabsorbed staining solution, leaving behind only the staining solution absorbed by the biofilm itself. A solvent can then be used to remove the absorbed crystal violet, and the extent to which the solvent changes color due to the presence of the crystal violet stain can be measured with a spectrophotometer. This color change is proportional to the quantity of biofilm present. In this way, biofilm formation in the presence of nanoparticles can be compared to the control biofilm.

\section{Live/dead staining}

The use of live/dead cell viability assays offers an additional and, arguably, more accurate representation of the presence of viable bacteria in solution or on a surface. The live/dead cell viability assay is a combination of two separate cell stains, one $\left(\right.$ Syto $^{\circledR} 9$ green fluorescent nucleic acid stain [Invitrogen Corporation, Carlsbad, CA], excitation 480 nm/ emission $500 \mathrm{~nm}$ ) which stains all cells living or dead, and 
one (propidium iodide, excitation $490 \mathrm{~nm} / \mathrm{emission} 635 \mathrm{~nm}$ ) which is only able to stain cells which have a compromised membrane and are, therefore, dead or dying. When used together, these dyes allow for the identification of both living and dead cells in a single sample. Once cell staining is complete, samples can be analyzed with a fluorescent plate reader or using fluorescence microscopy techniques. A fluorescent plate reader quantifies emissions at the excitation wavelengths of each stain. The peaks produced by each stain are compared to determine the approximate quantities of live and dead cells, and also the ratio of live cells to dead cells. Alternatively, bacteria grown on a surface (generally in biofilm form) can be analyzed using fluorescence microscopy techniques. The excitation wavelengths of the dyes are used to view both live and dead cells. This allows for visualization of the cells on the surface. At higher magnifications $(\geq 40 \times)$ individual bacteria are visible. For quantification, living and dead cells within the field of view can be counted. Confocal fluorescence microscopy can be used to collect three-dimensional data on the structure and thickness of the biofilm. However, for an accurate biofilm thickness estimate, sample surfaces must be very flat.

\section{Tetrazolium salt reduction assays}

A variety of assays estimate cell viability via the reduction of tetrazolium salts to formazan dyes. These assays are colorimetric, and the color change produced can be quantified with a spectrophotometer. MTT (3-[4,5Dimethylthiazol-2-yl]-2,5-diphenyltetrazolium bromide), XTT (2,3-bis-[2-methoxy-4-nitro-5-sulfophenyl]-2H-tetrazolium-5-carboxanilide), and MTS (3-[4,5-dimethylthiazol2-yl]-5-[3-carboxymethoxyphenyl]-2-[4-sulfophenyl]-2Htetrazolium) assays are reduced to formazan in the presence of reductase enzymes produced by living cells. The amount of formazan dye produced is proportionate to the quantity of viable cells present. In other words, the difference in color change between experimental and control groups of a known cell density can be attributed to the effectiveness of an antibacterial agent introduced to the experimental group. The amount of reductase enzyme produced by each cell is, however, related to metabolic activity. Cells with reduced metabolic activity, such as those in a biofilm, may produce a reduced amount of reductase enzyme, thus potentially producing artificially low cell numbers when viable cells are being quantified with this particular type of assay. Also, high densities of bacteria may produce the maximum amount of formazan product and the optical density of the sample may appear comparable to even greater cell densities.

\section{Antibacterial nanoparticles}

The antibacterial properties of a variety of nanostructures have been investigated. In understanding the antibacterial properties of these nanostructures, it is important to recognize that while some metals, such as zinc, silver, and copper, exhibit antibacterial mechanisms in their bulk form, other materials, such as iron oxide, are not antibacterial in their bulk form but may exhibit antibacterial properties in nanoparticulate form.

The mechanism of this antibacterial activity varies from nanoparticle to nanoparticle. For all varieties of nanoparticles, the antibacterial mechanism is not fully understood. While some proposed mechanisms relate to the physical structure of the nanoparticles (ie, membrane-damaging abrasiveness of the nanoparticle), others relate to the enhanced release of antibacterial metal ions from nanoparticle surfaces. The specific surface area of a dose of nanoparticles increases as the particle size decreases, allowing for greater material interaction with the surrounding environment. Thus, for inherently antibacterial materials, such as zinc and silver, increasing the surface to volume ratio enhances the antibacterial effect. A nanoparticle of an inherently antibacterial material may, therefore, have multiple mechanisms of antibacterial activity, such as the release of antibacterial metal ions from the particle surface and the antibacterial physical properties of a nanoparticle related to cell wall penetration or membrane damage.

Comparing results across a greater number of studies allows for the identification of nanoparticle parameters which are most relevant in designing the ideal antibacterial particle (Table 2). Chemistry, particle size, particle shape, and zeta potential are among the most relevant variables affecting antibacterial activity.

\section{Zinc oxide $(\mathrm{ZnO})$}

$\mathrm{ZnO}$ has been shown to naturally reduce the activity of a wide range of (mostly Gram-positive) bacteria strains without the use of antibiotics. ${ }^{5}$ Implementation of nanotechnology has further enhanced the antibacterial properties of $\mathrm{ZnO} .^{6-8}$

For example, a study that used particle supplements to liquid cell suspensions to investigate the antibacterial effect of both micronscale and nanoscale $\mathrm{ZnO}$ particles concluded that nanoparticles had a greater antibacterial effect. ${ }^{9} \mathrm{ZnO}$ nanoparticles (average mean diameter $=60 \mathrm{~nm}$, zeta potential under experimental conditions $=-5 \mathrm{mV}$ ) and micronscale $\mathrm{ZnO}$ particles were added to bacteria suspensions at a concentration of $20 \mu \mathrm{g} / \mathrm{mL}$, incubated for 2 hours, and then added to agar plates in order to count viable colonies. 
Table 2 Summary of select studies concerning the antimicrobial effects of nanoparticles

\begin{tabular}{|c|c|c|c|c|c|c|}
\hline Chemistry & $\begin{array}{l}\text { Size } \\
\text { (average) }\end{array}$ & $\begin{array}{l}\text { Zeta } \\
\text { potential }\end{array}$ & $\begin{array}{l}\text { Organism } \\
\text { tested }\end{array}$ & MIC & $\begin{array}{l}\text { Proposed } \\
\text { mechanism }\end{array}$ & Reference \\
\hline $\mathrm{ZnO}$ & $13 \mathrm{~nm}$ & N/A & $\begin{array}{l}\text { Staphylococcus } \\
\text { aureus }\end{array}$ & Reduced $95 \%$ at $80 \mu \mathrm{g} / \mathrm{mL}$ & ROS inhibition & Reddy ${ }^{10}$ \\
\hline $\mathrm{ZnO}$ & $60 \mathrm{~nm}$ & N/A & S. aureus & Reduced $50 \%$ at $400 \mu \mathrm{g} / \mathrm{mL}$ & ROS inhibition & Jones $^{2}$ \\
\hline $\mathrm{ZnO}$ & $40 \mathrm{~nm}$ & $\begin{array}{l}\text { Positive } \\
\text { (no value) }\end{array}$ & $\begin{array}{l}\text { S. aureus, } \\
\text { Escherichia coli }\end{array}$ & $\begin{array}{l}\text { Both species reduced } 99 \% \text { at } \\
400 \mu \mathrm{g} / \mathrm{mL}\end{array}$ & Membrane disruption & Nair"l \\
\hline $\mathrm{ZnO}$ & $12 \mathrm{~nm}$ & $\mathrm{~N} / \mathrm{A}$ & E. coli & Reduced $90 \%$ at $400 \mu \mathrm{g} / \mathrm{mL}$ & $\begin{array}{l}\text { Membrane damage due } \\
\text { to particle abrasiveness }\end{array}$ & Padmavathy ${ }^{12}$ \\
\hline $\mathrm{ZnO}$ ions & $\mathrm{N} / \mathrm{A}$ & N/A & $\begin{array}{l}\text { Pseudomonas } \\
\text { aeruginosa, } \\
\text { S. aureus, } \\
\text { Candida albicans }\end{array}$ & $\begin{array}{l}\text { Reduced } 100 \% \text { at } 1917,9 \text {, and } \\
39 \mu \mathrm{g} / \mathrm{mL} \text {, respectively }\end{array}$ & ROS inhibition & McCarthy ${ }^{13}$ \\
\hline Silver & $21 \mathrm{~nm}$ & N/A & $\begin{array}{l}\text { E. coli, } \\
\text { Vibrio cholerae, } \\
\text { Salmonella typhi, } \\
\text { P. aeruginosa }\end{array}$ & All reduced $100 \%$ at $75 \mu \mathrm{g} / \mathrm{mL}$ & $\begin{array}{l}\text { Membrane disruption, } \\
\text { Ag ion interference } \\
\text { with DNA replication }\end{array}$ & Morones ${ }^{18}$ \\
\hline Silver & $\begin{array}{l}\text { Triangles } \\
(50 \mathrm{~nm})\end{array}$ & $\begin{array}{l}\text { Positive } \\
\text { (no value, } \\
\text { cationic surfactant) }\end{array}$ & E. coli & $\begin{array}{l}\text { Reduced } 99 \% \text { with } 0.1 \mu \mathrm{g} / \mathrm{mL} \\
\text { added to agar surface }\end{array}$ & $\begin{array}{l}\text { Membrane disruption, } \\
\mathrm{Ag} \text { ion interference } \\
\text { with DNA replication }\end{array}$ & $\mathrm{Pa}^{20}$ \\
\hline Silver & $12 \mathrm{~nm}$ & $\begin{array}{l}\text { Negative } \\
\text { (no value) }\end{array}$ & E. coli & $\begin{array}{l}\text { Reduced } 70 \% \text { with } 10 \mu \mathrm{g} / \mathrm{mL} \\
\text { in agar }\end{array}$ & $\begin{array}{l}\text { Membrane disruption, } \\
\mathrm{Ag} \text { ion interference } \\
\text { with DNA replication }\end{array}$ & Sondi ${ }^{3}$ \\
\hline Silver & $13.5 \mathrm{~nm}$ & $-0.33 \mathrm{mV}$ & $\begin{array}{l}\text { S. aureus, } \\
\text { E. coli }\end{array}$ & $\begin{array}{l}\text { Inhibitory concentration of } \\
3.56 \mu g / \mathrm{L} \text { and } 0.356 \mu g / \mathrm{L} \text {, } \\
\text { respectively, added to agar surface }\end{array}$ & $\begin{array}{l}\text { Membrane disruption, } \\
\text { Ag ion interference } \\
\text { with DNA replication }\end{array}$ & $\mathrm{Kim}^{21}$ \\
\hline $\mathrm{Cu}$ & $100 \mathrm{~nm}$ & N/A & $\begin{array}{l}\text { E. coli, } \\
\text { Bacillus subtilis }\end{array}$ & $\begin{array}{l}\text { Reduced } 90 \% \text { at } 33.40 \mu \mathrm{g} / \mathrm{mL} \text { and } \\
28.20 \mu \mathrm{g} / \mathrm{mL} \text {, respectively }\end{array}$ & $\begin{array}{l}\text { Protein inactivation } \\
\text { via thiol interaction }\end{array}$ & Yoon $^{22}$ \\
\hline $\mathrm{Fe}_{3} \mathrm{O}_{4}$ & $9 \mathrm{~nm}$ & $-19.09 \mathrm{mV}$ & S. aureus & $\begin{array}{l}\text { Increased dead cells observed } \\
\text { at } 3 \mathrm{mg} / \mathrm{mL}\end{array}$ & $\begin{array}{l}\text { ROS, membrane } \\
\text { disruption }\end{array}$ & $\operatorname{Tran}^{24}$ \\
\hline $\mathrm{Fe}_{3} \mathrm{O}_{4}$ & $8 \mathrm{~nm}$ & $\mathrm{~N} / \mathrm{A}$ & $\begin{array}{l}\text { Staphylococcus } \\
\text { epidermidis }\end{array}$ & Reduced $65 \%$ at $2 \mathrm{mg} / \mathrm{mL}$ & $\begin{array}{l}\text { ROS, membrane } \\
\text { disruption }\end{array}$ & Taylor ${ }^{25}$ \\
\hline $\mathrm{Al}_{2} \mathrm{O}_{3}$ & II nm & $120 \mathrm{mV}$ & E. coli & $\begin{array}{l}\text { Reduced } 35 \%, 70 \% \text {, and } 68 \% \text { at } 10 \\
100 \text {, and } 500 \mu \mathrm{g} / \mathrm{mL} \text {, respectively }\end{array}$ & $\begin{array}{l}\text { Dose-dependent ROS, } \\
\text { particle penetration }\end{array}$ & $\begin{array}{l}\text { Simon- } \\
\text { Deckers }{ }^{26}\end{array}$ \\
\hline $\mathrm{Al}_{2} \mathrm{O}_{3}$ & $60 \mathrm{~nm}$ & $30 \mathrm{mV}$ & $\begin{array}{l}\text { E. coli, } \\
\text { B. subtilis, } \\
\text { Pseudomonas } \\
\text { fluorescens }\end{array}$ & $\begin{array}{l}\text { Reduced bacteria species by } 36 \% \text {, } \\
57 \% \text {, and } 70 \% \text { at } 20 \mu \mathrm{gL}\end{array}$ & Flocculation & Jiang 9 \\
\hline $\mathrm{TiO}_{2}$ & $17 \mathrm{~nm}$ & $12 \mathrm{mV}$ & E. coli & $\begin{array}{l}\text { Reduced } 0 \%, 35 \% \text {, and } 80 \% \text { with } \\
10 \text {, } 100 \text {, and } 500 \mu \mathrm{gL} \text {, respectively }\end{array}$ & Membrane disruption & $\begin{array}{l}\text { Simon- } \\
\text { Deckers }^{26}\end{array}$ \\
\hline $\mathrm{SiO}_{2}$ & $20 \mathrm{~nm}$ & $35 \mathrm{mV}$ & $\begin{array}{l}\text { E. coli, } \\
\text { B. subtilis, } \\
\text { P. fluorescens }\end{array}$ & $\begin{array}{l}\text { Reduced bacteria species } 58 \% \text {, } \\
40 \% \text {, and } 70 \% \text { at } 20 \mu \mathrm{gL} / \mathrm{mL}\end{array}$ & $\begin{array}{l}\text { Flocculation, membrane } \\
\text { disruption }\end{array}$ & Jiang ${ }^{9}$ \\
\hline Chitosan & $40 \mathrm{~nm}$ & $51 \mathrm{mV}$ & $\begin{array}{l}\text { E. coli, } \\
\text { S. aureus }\end{array}$ & $\begin{array}{l}\text { Reduced bacteria species } 100 \% \text { at } \\
4 \mu \mathrm{g} / \mathrm{mL} \text { and } 8 \mu \mathrm{g} / \mathrm{mL} \text {, respectively }\end{array}$ & $\begin{array}{l}\text { Flocculation, membrane } \\
\text { disruption }\end{array}$ & $\mathrm{Qi}^{27}$ \\
\hline
\end{tabular}

Abbreviations: $\mathrm{Ag}$, silver; $\mathrm{Al}_{2} \mathrm{O}_{3}$, aluminum oxide; $\mathrm{Cu}$, copper; $\mathrm{Fe}_{3} \mathrm{O}_{4}$, iron oxide; $\mathrm{MIC}$, minimum inhibitory concentration; $\mathrm{N} / \mathrm{A}$, not available; $\mathrm{ROS}$, reactive oxygen species; $\mathrm{SiO}_{2}$, silicon dioxide; $\mathrm{TiO}_{2}$, titanium dioxide; $\mathrm{ZnO}$, zinc oxide.

While micron-size $\mathrm{ZnO}$ particles reduced colony counts of Bacillus subtilis, Escherichia coli, and Pseudomonas fluorescens by $100 \%, 75 \%$, and $50 \%$, respectively, $\mathrm{ZnO}$ nanoparticles reduced viability of all bacteria species by $100 \%$ compared to controls. In both the micronscale and nanoparticle form, $\mathrm{ZnO}$ was more toxic to all bacteria species than other comparably-sized particle chemistries tested (such as aluminum oxide and silicon dioxide).
Complete inhibition of planktonic $S$. aureus growth has been observed at $\mathrm{ZnO}$ nanoparticle (mean average diameter $=13 \mathrm{~nm})$ concentrations of $\geq 1 \mathrm{mM}(81.408 \mu \mathrm{g} / \mathrm{mL})$ in overnight cultures. ${ }^{10}$ A $95 \%$ inhibition of $S$. aureus growth in the presence of $1 \mathrm{mM}$ of $8 \mathrm{~nm} \mathrm{ZnO}$ nanoparticles after 10 hours and a $40 \%-50 \%$ inhibition of the same $S$. aureus in the presence of $5 \mathrm{mM}(407.04 \mu \mathrm{g} / \mathrm{mL})$ of 50-70 nm ZnO nanoparticles after 10 hours was observed. ${ }^{2}$ 
While highlighting the discrepancies in the antibacterial effect among $\mathrm{ZnO}$ nanoparticles of varying sizes, the authors also commented on the potentially important role of ambient ultraviolet light in providing antibacterial properties to $\mathrm{ZnO}$. When comparable experiments were performed in the dark, high concentrations of $5 \mathrm{mM}$ of $8 \mathrm{~nm} \mathrm{ZnO}$ nanoparticles resulted in only a slight inhibition of bacterial growth after 10 hours. However, increased doses of ultraviolet light in addition to the ambient light of the laboratory did not enhance this antibacterial effect beyond ambient light conditions.

Reduced viability of S. aureus and E. coli was observed when the bacteria were exposed to $\mathrm{ZnO}$ nanoparticles of decreasing size. However, a concentration of $5 \mathrm{mM}$ ( $407.04 \mu \mathrm{g} / \mathrm{mL}$ ) was necessary to reduce viability of either bacteria species at 24 hours even with $40 \mathrm{~nm}$ diameter particles, the smallest diameter $\mathrm{ZnO}$ nanoparticle tested. ${ }^{11}$ The two bacteria species tested were affected approximately equally by the presence of nanoparticles. Irregularity in cell membranes of bacteria exposed to $\mathrm{ZnO}$ nanoparticles was also noted. An increased antimicrobial effect of $\mathrm{ZnO}$ nanoparticles on E. coli was observed at the 18-hour time point as the particle diameter was reduced from $2 \mu \mathrm{m}$ to $45 \mathrm{~nm}$ to $12 \mathrm{~nm}$, and this was attributed to the enhanced effect of the greater surface area to volume ratios and mechanical damage caused to the cells due to increased abrasiveness of the smaller nanoparticles. ${ }^{12}$

A study which investigated the antibacterial effects of zinc ions identified MIC of $1917 \mu \mathrm{g} / \mathrm{mL}, 9 \mu \mathrm{g} / \mathrm{mL}$, and $39 \mu \mathrm{g} / \mathrm{mL}$ at 48 hours for Pseudomonas aeruginosa, S. aureus, and Candida albicans, respectively. ${ }^{13,14}$ Compared to $P$. aeruginosa, S. aureus was found to be far more sensitive to lower concentrations of zinc ions.

In a study developed to elucidate the mechanisms of the antibacterial effect of $\mathrm{ZnO}$ particles, production of hydrogen peroxide, a reactive oxygen species attributed to bactericidal activity, in solutions with a variety of ceramic powder chemistries was determined. ${ }^{15} \mathrm{ZnO}$ produced the greatest amount of hydrogen peroxide and the antibacterial effect of $\mathrm{ZnO}$ powders was attributed to this phenomenon. Hydrogen peroxide production was not detected with other ceramic powders tested (such as magnesium oxide and calcium oxide).

Yet, the mechanism of the antibacterial activity of $\mathrm{ZnO}$ nanoparticles is complex and not fully understood. Zinc ions are known to inhibit multiple activities in the bacterial cell, such as glycolysis, transmembrane proton translocation, and acid tolerance. ${ }^{16}$ In contrast to the presence of $\mathrm{ZnO}$ nanoparticles, the presence of zinc ions is likely only able to inhibit bacteria proliferation (bacteriostatic), rather than killing bacteria (bactericidal). The production of reactive oxygen species and the disruption of cell membranes (Figure 1) caused by $\mathrm{ZnO}$ nanoparticles may actually be bactericidal. However, Dimkpa et al found that while the presence of $\mathrm{ZnO}$ nanoparticles resulted in a dose-dependent increase in the presence of reactive oxygen species, this increase in reactive oxygen species resulted in only
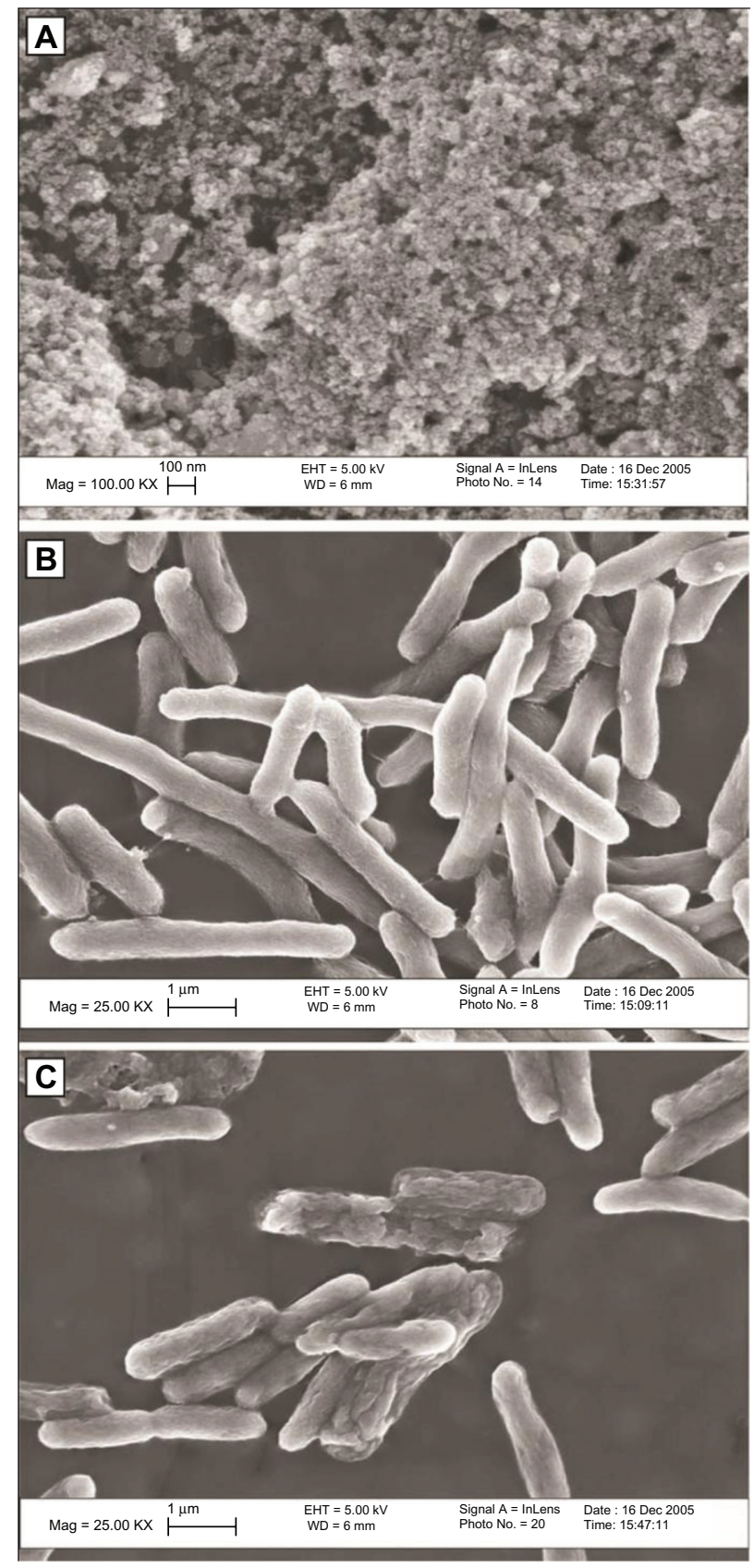

Figure I Zinc oxide $(\mathrm{ZnO})$ nanoparticles $(\mathbf{A})$, Escherichia coli bacteria prior to exposure to $\mathrm{ZnO}$ nanoparticles $(\mathbf{B})$, and $E$. coli bacteria after exposure to $\mathrm{ZnO}$ nanoparticles $(\mathbf{C})$. Membrane irregularities were observed in bacteria exposed to $\mathrm{ZnO}$ nanoparticles. With kind permission from Springer Science+Business Media: Journal of Nanoparticle Research. Investigation into the antibacterial behaviour of suspensions of $\mathrm{ZnO}$ nanoparticles (ZnO nanofluids). 9(3), 2007, page 483. Zhang L. Figure $2 .^{8}$ 
minimal bactericidal activity to bacteria species Pseudomonas chlororaphis $06 .{ }^{17}$ All considered, the bactericidal properties of $\mathrm{ZnO}$ depend on multifactorial antibacterial mechanisms. For bacteria grown in suspension in vitro, literature suggests that smaller diameter particles are more effective at reducing bacteria activity than larger particles with identical chemistry. $2,11,12$

\section{Silver}

The historical use of silver as an antibacterial agent made the progression to silver nanoparticles a logical and compelling step. As a naturally antibacterial metal, a silver nanoparticle likely has multiple mechanisms of antibacterial activity.

Silver nanoparticles with an average diameter of $21 \mathrm{~nm}$ were shown to inhibit the growth of Gram-negative bacteria species (E. coli, Vibrio cholerae, Salmonella typhi, and $P$. aeruginosa) on agar plates with nanoparticle concentrations at or above $75 \mu \mathrm{g} / \mathrm{mL}$. ${ }^{18}$ The authors attributed the bactericidal effect of silver nanoparticles to a number of mechanisms. First, membrane permeability was thought to be effected. The presence of a large number of nanoparticles inside the bacteria suggests that this is an important mechanism. Interaction of silver particles with bacteria membrane and intracellular proteins, particularly sulfurcontaining membrane proteins and phosphorus-containing DNA, interferes with cell division and causes cell death. The authors also confirmed the presence of biocidal ionic silver released from nanoparticle surfaces. Upon exposure to ionic silver, bacteria DNA conglomeration defense mechanisms protect it from a toxic surrounding environment but this compromises bacteria replication ability. Thus, the responses to ionic silver and nanoparticles are different, but both are essential to a complete understanding of the antibacterial activity of silver nanoparticles.

In a study comparing the morphological features of Grampositive ( $S$. aureus) and Gram-negative (E. coli) bacteria exposed to the same concentration of silver ions $(10 \mu \mathrm{g} / \mathrm{mL}$ silver nitrate for 4-12 hours), both bacteria species exhibited condensation of DNA, cell membrane separation from the cell wall, and cell wall damage. ${ }^{19}$ These characteristics are indicative of distressed bacteria that are being damaged. Furthermore, silver ions were detected within the cytoplasm of each bacteria type. These observations further clarified the role of the metal ion component in the antibacterial mechanism of silver.

A study designed to compare antibacterial properties of silver nanostructures of different shapes concluded that truncated triangular silver nanoplates and nanospheres were more effective at reducing $E$. coli viability than silver nanorods or ionic silver. ${ }^{20}$ Various volumes of silver nanostructures were added to agar plates plated with bacteria cell suspensions. Colony formation was almost completely inhibited when $1 \mu \mathrm{g}$ of triangular silver nanoplates with a width of about $50 \mathrm{~nm}$ was added to the agar plate of $10^{6} \mathrm{CFUs}$. To comparably reduce bacteria activity with spherical nanoparticles, $12.5 \mu \mathrm{g}$ was needed. Dose-dependent inhibition of bacteria activity was observed for all shapes of silver nanostructures, with triangular silver nanoplates exhibiting the greatest antibacterial activity at low doses. The process of producing nanoplates may have resulted in the addition of a positive charge to the particle surface that enhanced electrostatic interactions between particles and cells. This, along with the increased number of active facets on a triangular-shaped particle, was the explanation offered for the superior antibacterial activity of triangular particles, but the antibacterial activity of all silver nanostructures was attributed to silver ion interference with cell membrane integrity, the respiratory chain, and DNA replication.

To determine the ability of silver nanoparticle concentrations to reduce bacteria growth on agar plates, silver nanoparticles with an average diameter of $12 \mathrm{~nm}$ were incorporated into agar plates at concentrations of $10-100 \mu \mathrm{g} / \mathrm{mL} .^{3}$ E. coli was added to the plates at population densities of $10^{5} \mathrm{CFUs}$. After 24 hours of growth, CFU populations on $10 \mu \mathrm{g} / \mathrm{mL}$ plates were $70 \%$ lower than on control plates which did not contain silver nanoparticles. A concentration-dependent inhibition of bacteria growth was observed as silver nanoparticle concentrations increased. Concentrations above $50 \mu \mathrm{g} / \mathrm{mL}$ completely inhibited $E$. coli growth. A separate experiment determined that for a fixed concentration of nanoparticles, the growth of low bacteria seeding densities was completely inhibited while higher seeding densities were not. However, these higher seeding densities were above and beyond cell densities relevant to infection. When grown in lysogeny broth medium suspension, growth curves were only slightly reduced at $10 \mu \mathrm{g} / \mathrm{mL}$ concentrations of nanoparticles and were reduced by about $50 \%$ after 9 hours in the presence of $100 \mu \mathrm{g} / \mathrm{mL}$. As nanoparticle concentrations increased, some delay in growth was observed. The authors attributed the antibacterial activity to the same phenomena discussed by authors of other previous studies, including membrane interference (Figure 2). While the silver nanoparticles appeared to somehow attach to the cell wall of the bacteria, the interaction was likely lower than it would have been if the particles had a positive rather than a negative charge. 


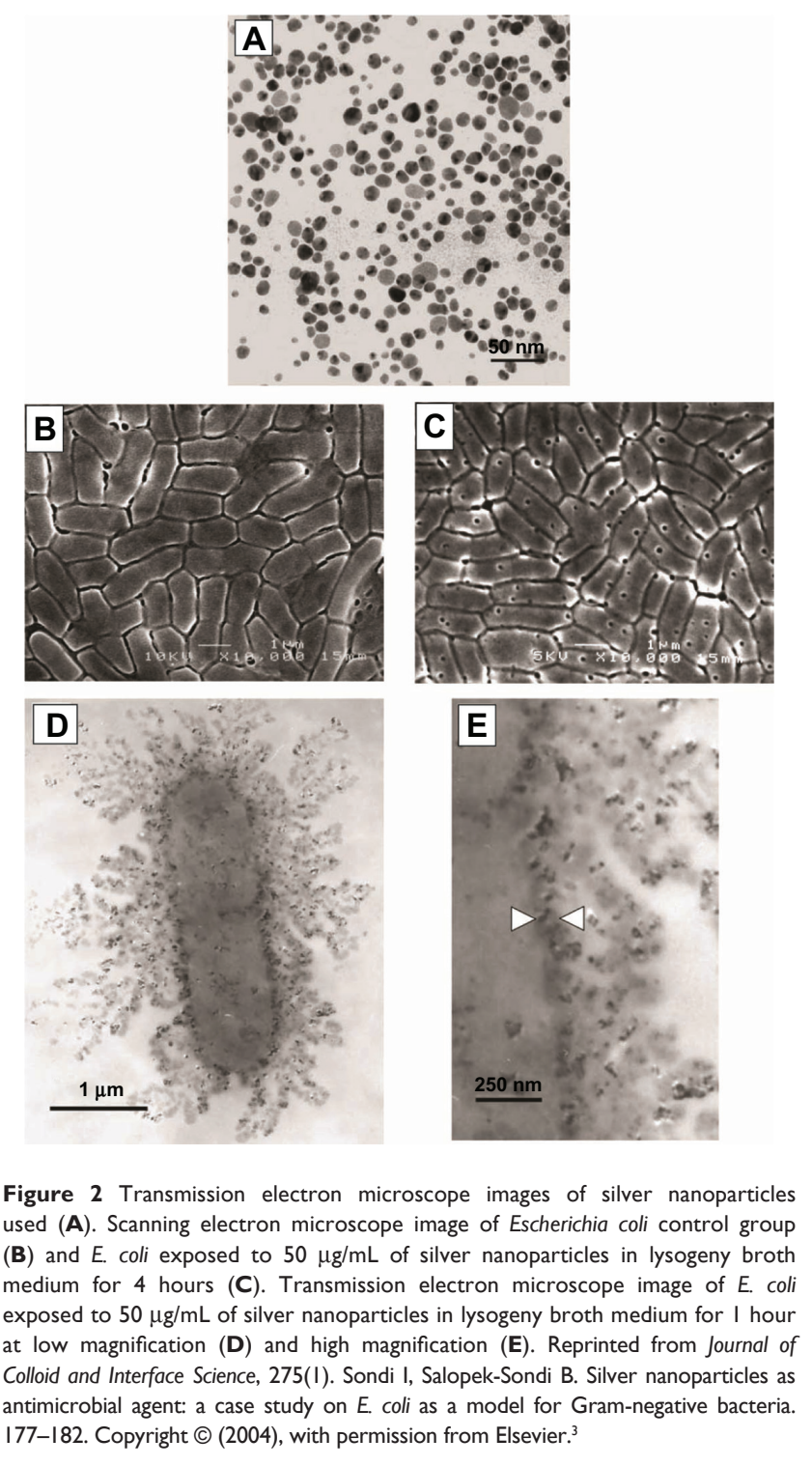

$S$. aureus and E. coli were exposed to silver nanoparticles (mean average diameter $=13.5 \mathrm{~nm}$, zeta potential under experimental conditions $=-0.33 \mathrm{mV}$ ) by adding $20 \mu \mathrm{L}$ of a silver nanoparticle solution (of concentrations ranging from $21.54 \mathrm{ng} / \mathrm{L}$ to $3.56 \mu \mathrm{g} / \mathrm{L}$ ) directly to the surface of agar plates inoculated with $10^{7}$ CFUs. ${ }^{21}$ The MIC for $E$. coli was estimated to be $0.356 \mu \mathrm{g} / \mathrm{L}$. For $S$. aureus, MIC values were determined to be somewhere above $3.56 \mu \mathrm{g} / \mathrm{L}$, the highest concentration used in this study. The MIC for $E$. coli was far lower than the results from other studies due to differences in experimental methods such as the application of silver nanoparticles directly to the agar surface rather than incorporated throughout the volume of the agar.

\section{Copper}

Conventional copper, like conventional silver, exhibits antibacterial properties. Copper nanoparticles (mean average diameter $=100 \mathrm{~nm}$ ) added to agar plates reduced E. coli and B. subtilis survival by $90 \%$ at concentrations of $33.40 \mu \mathrm{g} / \mathrm{mL}$ and $28.20 \mu \mathrm{g} / \mathrm{mL}$, respectively. ${ }^{22}$ The growth of both bacteria species was completely inhibited at nanoparticle concentrations above $60 \mu \mathrm{g} / \mathrm{mL}$. Incidentally, in order to evaluate the difference in antibacterial effect of different metals, slightly smaller (mean average diameter $=40 \mathrm{~nm}$ ) silver nanoparticles were also tested. Concentrations of silver nanoparticles necessary to reduce $E$. coli and $B$. subtilis survival by $90 \%$ were $58.4 \mu \mathrm{g} / \mathrm{mL}$ and $32.12 \mu \mathrm{g} / \mathrm{mL}$, respectively, higher than the concentrations of copper required. The authors proposed that the mechanism by which the copper nanoparticles reduced bacteria viability was related to protein inactivation via thiol interaction.

In another study that utilized a unique method of impregnating filter paper with nanoparticles and placing pieces of filter paper on inoculated agar plates, the MIC of copper nanoparticles (mean average diameter $=10 \mathrm{~nm}$ ) was determined to be $140-280 \mu \mathrm{g} / \mathrm{mL}$ for $E$. coli, depending on the strain tested, and $140 \mu \mathrm{g} / \mathrm{mL}$ for $S$. aureus strains. ${ }^{23}$ The MBC were $160-300 \mu \mathrm{g} / \mathrm{mL}$ for the E. coli strains and $160 \mu \mathrm{g} / \mathrm{mL}$ for the $S$. aureus strains. B. subtilis was found to be most sensitive to copper nanoparticles with an MIC of $20 \mu \mathrm{g} / \mathrm{mL}$ and an MBC of $40 \mu \mathrm{g} / \mathrm{mL}$. The authors commented on the difficulty of separating the antibacterial effect of the copper ions released from the nanoparticle surfaces and the antibacterial effect of the nanoparticles themselves. A separate study first observed the antibacterial effect of copper nanoparticles and then eliminated that antibacterial activity with the addition of a copper ion-specific chelator, bathocuproine, to demonstrate the importance of the role of copper ions in the antibacterial mechanism.

Interestingly, in a study summarized above, the Grampositive bacteria species, $S$. aureus, was more sensitive to copper nanoparticles than the Gram-negative species, E. coli. Considering the presence of the thick peptidoglycan layer in Gram-positive species, the purpose of which is to provide an additional structural barrier to harmful elements in the environment, it is somewhat counter-intuitive and surprising that a Gram-positive species would be more vulnerable to the antibacterial effect of any variety of nanoparticle.

\section{Iron oxide}

Although conventional iron oxide is not considered antibacterial, a few studies on its effect on bacteria have been conducted and inhibition of bacteria activity has been observed. For example, iron oxide nanoparticles (mean average diameter $=9 \mathrm{~nm}$, zeta potential under experimental 
conditions $=-19.09 \mathrm{mV}$ ) in a chain-like structure with a length of 100-200 nm were shown to reduce $S$. aureus viability as illustrated by a decrease in the ratio of live to dead cells. ${ }^{24}$ At concentrations of $3 \mathrm{mg} / \mathrm{mL}$, iron oxide nanoparticles were shown to reduce cell viability at 4,12 , and 24 hours compared to bacteria culture controls without nanoparticles and compared to lower concentrations of nanoparticles. The antibacterial mechanism of iron oxide nanoparticles was thought to be related to the ability of nanoparticles to penetrate into the cell and generate reactive oxygen species. The negative zeta potential of the nanoparticles, and minimal electrostatic interactions with negative bacteria surface charges, may explain why relatively high concentrations of nanoparticles were needed to produce an antibacterial effect.

As another example, iron oxide nanoparticles (mean average diameter $=8 \mathrm{~nm}$ ) in Staphylococcus epidermidis suspensions reduced cell numbers at 12-, 24-, and 48-hour time points in a dose-dependent matter, according to optical density readings. ${ }^{25}$ After 48 hours, a concentration of $2 \mathrm{mg} / \mathrm{mL}$ reduced cell populations by about $65 \%$ compared to control groups with no nanoparticles. High concentrations of nanoparticles $(100 \mu \mathrm{g} / \mathrm{mL}, 1 \mathrm{mg} / \mathrm{mL}$, and $2 \mathrm{mg} / \mathrm{mL})$ also increased the number of dead cells observed during a live/dead assay. Antibacterial activity was again attributed to increasing oxidative stress and bacteria membrane interference.

Iron oxides are of particular interest not only due to their inherent antibacterial properties, but also due to their superparamagnetic properties that could allow such particles to be directed inside the body with a magnetic field, possibly after coating with some type of antimicrobial agent.

\section{Miscellaneous nanoparticle chemistries}

The antibacterial properties of a variety of other nanoparticle chemistries have been studied, often as a control group for other nanoparticle chemistries hypothesized to exhibit a strong antibacterial effect. The survival rate of Gramnegative $E$. coli was evaluated in the presence of spherical, small diameter $(\sim 11 \mathrm{~nm}$, zeta potential under experimental conditions $=120 \mathrm{mV}$ ) nanoparticles of aluminum oxide..$^{26}$ A live/dead assay determined that 10,100 , and $500 \mu \mathrm{g} / \mathrm{mL}$ of aluminum oxide nanoparticles in aqueous bacteria suspensions reduced $E$. coli viability to $65 \%, 30 \%$, and $32 \%$ survival, respectively, after 24 hours. The viability of Cupriavidus metallidurans was not affected by the presence of aluminum oxide nanoparticles, however, nanoparticles were observed on the cell membranes and in the periplasmic space of both bacteria species. Furthermore, a dose-dependent presence of reactive oxygen species was detected in both bacteria species. The authors speculated that the positive zeta potential of the nanoparticles enhanced the interaction between particles and cell membranes, and allowed for nanoparticle penetration into the cell and subsequent reactive oxygen species generation due in part to the presence of aluminum ions. For E. coli, this interaction reduced viability. It was speculated that the survival of $C$. metallidurans may be due to the increased expression of membrane restoration elements that protect the bacteria.

In a different study, aluminum oxide nanoparticles (mean average diameter $=60 \mathrm{~nm}$, zeta potential under experimental conditions $=30 \mathrm{mV}$ ) at a concentration of $20 \mu \mathrm{g} / \mathrm{mL}$ in a bacteria suspension of $E$. coli (zeta potential under experimental conditions $=-7.2 \mathrm{mV}$ ), B. subtilis (zeta potential under experimental conditions $=-41.3 \mathrm{mV}$ ), or P. Aluorescens (zeta potential under experimental conditions $=-32.3$ ) reduced cell viability to $64 \%, 43 \%$, and $30 \%$ of controls, respectively, as determined by optical density measurements of cell suspensions. ${ }^{9}$ In contrast, micronscale aluminum oxide powder (diameter $=400-1000 \mathrm{~nm}$ ) at the same concentration did not reduce the viability of any of the bacteria species. Bacteria flocculation was observed in the presence of nanoparticles and was attributed to the negatively-charged bacteria drawn in to the positivelycharged nanoparticles. A substantial amount of nanoparticles were observed on the bacteria surfaces and may have interfered with cell membrane integrity.

A variety of titanium dioxide nanoparticles (mean average diameter $=12-707 \mathrm{~nm}$, zeta potential under experimental conditions $=-50-44 \mathrm{mV}$ ) were added to aqueous bacteria suspensions at concentrations of 10,100 , and $500 \mu \mathrm{g} / \mathrm{mL}$ and were tested for viability with a live/dead assay. ${ }^{26} \mathrm{Of}$ all the various particle diameters and zeta potentials tested, the titanium dioxide particles that were ineffective at reducing bacteria viability were either large (770 nm diameter) or had a negative zeta potential. Small diameter nanoparticles of approximately the same size exhibited a greater antibacterial effect when the zeta potential was more positive. After 24 hours, the viability of $E$. coli in the presence of 10,100 , and $500 \mu \mathrm{g} / \mathrm{mL}$ of titanium dioxide nanoparticles with a diameter of $17 \mathrm{~nm}$ and a zeta potential of $12 \mathrm{mV}$ was $100 \%, 65 \%$, and $20 \%$, respectively. The presence of all varieties of nanoparticles was observed at the surface of cell membranes, but only particles with a positive zeta potential were observed in the periplasmic space. This suggests that zeta potential plays a significant role in a particle's ability to 
penetrate into cell bodies. The presence of reactive oxygen species was observed for all titanium dioxide nanoparticle types, even those which did not reduce bacteria viability. Therefore, the authors of the study concluded the interference with membrane integrity was the most significant contributing factor to the antibacterial mechanism.

Silicon dioxide nanoparticles (mean average diameter $=20 \mathrm{~nm}$, zeta potential under experimental conditions $=35 \mathrm{mV}$ ) in a cell suspension at a concentration of $20 \mu \mathrm{g} / \mathrm{mL}$ have been observed to reduce bacteria viability of $E$. coli (zeta potential under experimental conditions $=-7.2 \mathrm{mV}$ ), B. subtilis (zeta potential under experimental conditions $=-41.3 \mathrm{mV}$ ), or $P$. fluorescens (zeta potential under experimental conditions $=-32.3$ ) after 24 hours to $42 \%, 60 \%$, and $30 \%$ of controls, respectively. ${ }^{9}$ Micronscale silicon dioxide powder did not reduce the viability of any of the bacteria species. Electrostatic interactions between nanoparticles and bacteria was believed to contribute to nanoparticle binding to cell membranes, membrane interference, and reduced cell viability. The positively-charged nanoparticles interacted with negatively-charged bacteria cell surfaces to promote flocculation, a phenomenon not observed in the presence of micronscale particles with matching chemistry and charge.

In addition to metal and metal oxide nanoparticles, naturally-occurring polymer varieties including chitosan have been investigated for their antibacterial properties. An in vitro study which investigated the antibacterial effects of chitosan nanoparticles (mean diameter $=40 \mathrm{~nm}$, zeta potential under experimental conditions $=51 \mathrm{mV}$ ) on planktonic bacteria in water via an optical density method reported an MIC of $0.125 \mu \mathrm{g} / \mathrm{mL}$ and $0.25 \mu \mathrm{g} / \mathrm{mL}$ for $E$. coli and $S$. aureus, respectively. ${ }^{27}$ The $\mathrm{MBC}$ was $4 \mu \mathrm{g} / \mathrm{mL}$ and $8 \mu \mathrm{g} / \mathrm{mL}$ for $E$. coli and $S$. aureus, respectively. In this study, $\mathrm{MIC}$ and MBC values were cut approximately in half when the chitosan nanoparticles were loaded with copper (which increased both particle diameter and zeta potential to $257 \mathrm{~nm}$ and $95 \mathrm{mV}$, respectively). Both chitosan nanoparticles and copper-loaded nanoparticles had a lower MIC and MBC than control groups exposed to doxycycline. The antibacterial effect of the nanoparticles was attributed to induced cell agglomeration and disruption of cell membranes.

A separate study looked specifically at the zeta potential of submicron chitosan particles and its role in the agglomeration of bacteria. ${ }^{28}$ The particles synthesized with the greatest positive zeta potential (mean average diameter $=380 \pm 57 \mathrm{~nm}$, zeta potential under experimental conditions $=51.1 \pm 2.2 \mathrm{mV}$ ) more effectively promoted agglomeration in $E$. coli (zeta potential under experimental conditions $=-14.7 \pm 1.3$ ) cell suspensions than low zeta potential submicron chitosan particles (mean average diameter $=199 \pm 9 \mathrm{~nm}$, zeta potential under experimental conditions $=29.4 \pm 4.6 \mathrm{mV}$ ). This suggests that, in terms of promoting bacteria agglomeration, zeta potential is the key factor. Chitosan-coated alginate particles with a negative zeta potential did not promote agglomeration of the $E$. coli. The degree of bacteria agglomeration in the presence of particles with a positive zeta potential was dependent on the concentration of chitosan particles.

A study investigating the antibacterial effect of purified single-wall carbon nanotubes (diameter $\sim 1 \mathrm{~nm}$, length $\sim 1 \mu \mathrm{m}$ ) found that a number of factors governed the magnitude of the antibacterial effect. ${ }^{29}$ For E. coli, P. aeruginosa, B. subtilis, and $S$. aureus, the viability of a cell suspension of $10^{6}-10^{7}$ $\mathrm{CFU} / \mathrm{mL}$ was reduced to about $65 \%, 72 \%, 45 \%$, and $50 \%$, respectively, in the presence of carbon nanotubes for 2 hours at a concentration of $5 \mu \mathrm{g} / \mathrm{mL}$. The addition of $0.1 \%$ Tween-20 ${ }^{\circledR}$ (ICI Americas, Inc, Wilmington, DE), which dispersed the carbon nanotubes and prevented agglomeration, significantly increased the antibacterial effect on each bacteria species. The rate at which the samples were shaken on an orbital shaker during incubation also affected the antibacterial activity. Independent of the presence of surfactants, E. coli and B. subtilis were killed more effectively during a shaking incubation compared to a stationary incubation. Furthermore, the antibacterial effect increased yet again when the rate of shaking was increased. To better understand the antibacterial effect of carbon nanotubes, surface stiffness of the bacteria species was measured with atomic force microscopy. The bacteria species most affected by carbon nanotubes, Grampositive $S$. aureus and B. subtilis, were found to be the less stiff bacteria species. The susceptibility of softer bacteria, the increased antibacterial effect of carbon nanotubes with higher kinetic energy, and the increased antibacterial effect of dispersed carbon nanotubes suggests that the antibacterial mechanism may relate to the ability of nanotubes to puncture cell membranes and disrupt cell activity in that manner.

\section{Summary of mechanisms}

Looking at these studies collectively, certain antibacterial mechanisms seem to be independent of particle chemistry. Small nanoparticles ( $\leq 30 \mathrm{~nm}$ ) appear to be the most capable of penetrating into bacteria cell bodies. Interference with cell membranes, and subsequent loss of cell viability, is attributed to nearly all varieties of nanoparticles, but particularly those with a small diameter and positive zeta potential. 
The electrostatic interaction of nanoparticles with positive zeta potential and negatively-charged bacteria surfaces draws the particles to the bacteria and promotes penetration into the membrane. Reactive oxygen species generation is also a nearly universally described mechanism of nanoparticle antibacterial activity, though one study measured comparable levels of reactive oxygen species even at low doses of nanoparticles that did not reduce cell viability. ${ }^{26}$ The physical presence of a nanoparticle most likely disrupted cell membranes in a dose-dependent manner.

Observed antibacterial effects of $\mathrm{ZnO}$ nanoparticles are not entirely consistent, but, based primarily on its susceptibility to ionic zinc, it appears that Gram-positive bacteria may be more susceptible to the reduction in viability than Gram-negative bacteria. Silver nanoparticles, however, were shown to be more effective at reducing viability of Gram-negative bacteria in at least one comparison study. ${ }^{21}$ While $\mathrm{ZnO}$ produces reactive oxygen species (particularly in the presence of ultraviolet light) that interfere with cell functions, silver ions disrupt DNA replication and cell division. Both particle chemistries also appear to compromise bacteria membrane integrity due to physical interactions.

A strongly positive zeta potential of a nanoparticle promotes nanoparticle interactions with cell membranes, membrane disruption, bacteria flocculation, and a reduction in viability. Zeta potential, along with particle size and chemistry, is a highly relevant parameter controlling antimicrobial effects. Considering previous studies as a whole, one can speculate that a very smaller diameter $(<30 \mathrm{~nm})$ nanoparticle of silver or $\mathrm{ZnO}$ that has been prepared to exhibit a positive surface charge will be the most effective to reducing bacteria viability.

\section{Antibacterial nanoparticles and eukaryotic cells}

The potential in vivo use of nanoparticles as an antibacterial agent is dependent on cytotoxicity to eukaryotic cells. In short, the concentrations of nanoparticles needed to kill bacteria cannot exceed concentrations which would substantially compromise functions of eukaryotic cells. While all varieties of nanoparticles could potentially exhibit cytotoxic properties, the summary presented here will be limited to only $\mathrm{ZnO}$ and silver nanoparticle varieties.

To investigate the cytotoxicity of $\mathrm{ZnO}$ nanoparticles on a model neural cell, ${ }^{30} 3 \times 10^{4}$ mouse neuroblastoma $2 \mathrm{~A}$ cells were first added to 96-well plates and incubated for 24 hours. $\mathrm{ZnO}$ nanoparticles (mean average diameter $=70 \mathrm{~nm}$ ) were then added to the cell culture media at concentrations of
$10,25,50$, and $100 \mu \mathrm{g} / \mathrm{mL}$. After 12 hours of exposure to nanoparticles, an MTT viability assay was used to quantify the number of cells present. Concentrations of 10, 25, 50, and $100 \mu \mathrm{g} / \mathrm{mL}$ reduced cell viability to $90 \%, 80 \%, 55 \%$, and $10 \%$ of control groups, respectively. Another similar study investigated the viability of human astrocytoma U87 cells in the presence of $\mathrm{ZnO}$ nanoparticles (diameter $\leq 100 \mathrm{~nm}$ ). ${ }^{31}$ U87 cells were added to 96-well plates and exposed to varying concentrations of nanoparticles added to the cell culture media. At concentrations of $1 \mu \mathrm{g} / \mathrm{mL}$ or less, cell viability was not affected. At a $\mathrm{ZnO}$ nanoparticle concentration of $10 \mu \mathrm{g} / \mathrm{mL}$ cell viability was reduced to about $55 \%$ of control. Concentrations at or above $25 \mu \mathrm{g} / \mathrm{mL}$ reduced cell viability to less than $5 \%$.

$\mathrm{ZnO}$ nanoparticles and their potential toxicity to lung epithelial cells was investigated in vitro by culturing A549 type II lung epithelial cells in the presence of $40 \mu \mathrm{g} / \mathrm{mL}$ and $80 \mu \mathrm{g} / \mathrm{mL} \mathrm{ZnO}$ nanoparticles (mean average diameter $=71 \mathrm{~nm}$, zeta potential under experimental conditions $=26.9 \mathrm{mV}) .{ }^{32}$ After 18 hours, cells were rinsed, trypsinated, stained with trypan blue, and counted using a hemocytometer. Cell viability was reduced to $75 \%$ and $62 \%$ for $40 \mu \mathrm{g} / \mathrm{mL}$ and $80 \mu \mathrm{g} / \mathrm{mL}$ concentrations, respectively. The presence of reactive oxygen species was not significantly increased compared to control groups for either concentration of nanoparticles. While $40 \mu \mathrm{g} / \mathrm{mL}$ of nanoparticles did not significantly increase DNA damage, $80 \mu \mathrm{g} / \mathrm{mL}$ resulted in a small but significant increase in DNA damage and oxidative DNA lesions. Cytotoxicity and DNA damage was attributed in large part to the presence of ionic zinc.

The cytotoxicity of $\mathrm{ZnO}$ nanoparticles (mean average diameter $=19 \mathrm{~nm}$ ) was tested on human mesothelioma MSTO-211H and rodent $3 \mathrm{~T} 3$ fibroblast cells. ${ }^{33}$ After 3 days, nanoparticle concentrations of $3.75 \mu \mathrm{g} / \mathrm{mL}$ did not significantly reduce viability, $7.5 \mu \mathrm{g} / \mathrm{mL}$ reduced viability of both cell types to about $75 \%$, and concentrations at or above $15 \mu \mathrm{g} / \mathrm{mL}$ killed nearly all cells present. The authors of the study partially attributes the toxicity of $\mathrm{ZnO}$ nanoparticles to the release of zinc ions and note that it is unclear whether ion release before or after nanoparticle uptake by the cells is most relevant. They also note that at nanoparticle concentrations of $15 \mu \mathrm{g} / \mathrm{mL}$, a critical amount of zinc was present to radically inhibit cell viability. Comparing to previous literature which established the cytotoxic threshold for ionic zinc, values of $32 \mathrm{ppm}^{34}$ and $10 \mathrm{ppm}^{35}$ were found.

The toxicity of silver nanoparticles (mean average diameter $=10 \mathrm{~nm}$ ) to human fibroblast cells was determined by adding nanoparticle-supplemented cell culture media to 
a fixed number of cells and performing viability assays at 24, 48, and 72 hours. ${ }^{36}$ Nanoparticle concentrations of 0,25 , $50,100,200,400 \mu \mathrm{g} / \mathrm{mL}$ reduced cell viability to $100 \%, 95 \%$, $90 \%, 80 \%, 75 \%$, and $60 \%$, respectively, compared to control groups at 24 hours. Additional reductions in viability were observed at 48 hours and 72 hours. At the 72-hour time point, nanoparticle concentrations at or above $200 \mu \mathrm{g} / \mathrm{mL}$ reduced viability to less than $50 \%$ of control. The authors attributed the dose-dependent toxicity of silver nanoparticles to the generation of reactive oxygen species and DNA damage which resulted in cell cycle arrest.

Collectively, these studies suggest that nanoparticle concentrations required to inhibit bacteria activity may have local cytotoxic effects. Concentrations of nanoparticles necessary for the treatment of an infection must be limited to the proximity of the bacteria being treated. Relatively large doses of nanoparticles introduced to the infection site will become less concentrated as they dissipate throughout the body. Ideally, techniques to confine the nanoparticles to the site of infection can be developed.

\section{Antibacterial nanorough surfaces}

Surface chemistry and topography, including nanoscale topography, has been extensively studied in relation to eukaryotic cells, but is less understood in relation to bacteria. However, the limited number of studies so far has shown much promise.

The purpose of most antibacterial nanorough surfaces is to prevent bacteria adhesion and subsequent biofilm formation, the hallmark of infection. It is the colonization of a biomaterial surface with bacteria that is a great threat to the efficacy of the medical device. So while physical attraction to bacteria is a desirable property in antibacterial nanoparticles, it is an undesirable property for nanomaterial surfaces. Positive zeta potential has been identified as an essential material property in nanoparticles, but may need to be avoided in antibacterial nanorough surfaces. The positive zeta potential, or surface charge, of a material surface may attract bacteria the same way that nanoparticles are attracted to the surface of bacteria. While nanoparticles may kill the bacteria, surfaces may be colonized more aggressively. Therefore, material surfaces should ideally have a negative surface charge in order to minimize the interaction with negatively-charged bacteria.

Some of the mechanisms thought to be most relevant to the antibacterial activity of nanoparticles may not be applicable to nanorough surfaces. Specifically, for particles that reduce bacteria viability primarily by penetrating into the bacteria cell body and compromising membrane integrity, a nanorough surface of comparable chemistry may not be strongly antibacterial. Other mechanisms related to the heightened antibacterial activity of nanomaterials, such as increased ion release, may be similarly heightened on nanorough surfaces as well due to increased functional surface area. However, other unique mechanisms may govern the antibacterial properties of materials which do not exhibit antibacterial properties on conventional topography surfaces.

Micronscale roughness has been identified as an undesirable property in biomaterial surfaces due to the bacteria's ability to more easily establish the biofilm in grooves or pits on the material surface. However, the interaction between bacteria and nanorough surfaces, though not well understood, may theoretically reduce the adhesion of bacteria. Elements of the initial bacterial adhesion process are regulated by electrostatic interactions that may be enhanced when the cell wall of a bacterium can lay flush against a material surface. Roughness on the nanoscale may prevent close contact of the cell wall and material surface due to the relative rigidity of the cell wall. In contrast to a eukaryotic cell, which is very

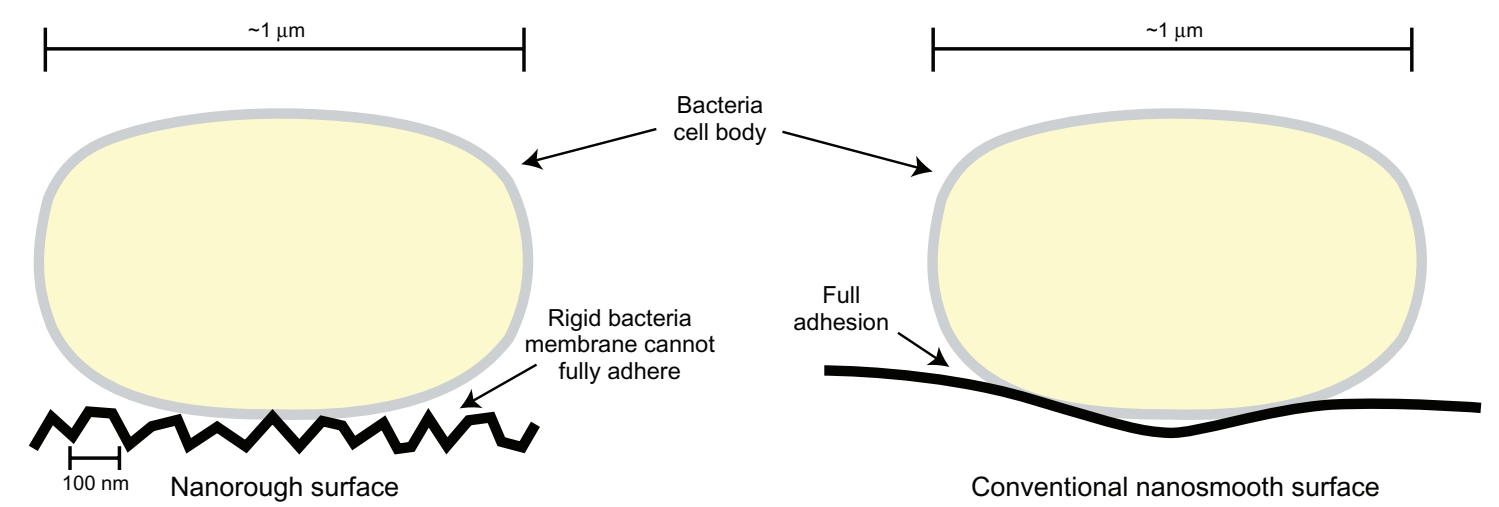

Figure 3 Illustration comparing bacteria surface interactions with nanorough surfaces and conventional nanosmooth surfaces. Due to the high degree of roughness on nanomaterials, rigid bacteria cell membranes cannot lay flush against the material surface. This may inhibit the preliminary steps which lead to bacteria adhesion. As a result, bacteria activity on a nanomaterial surface may be reduced. 
flexible, a bacteria cell wall may be unable to conform to the topography of a material with nanoscale surface features, inhibiting the early stages of bacteria adhesion (Figure 3 ).

One promising approach to antibacterial surfaces is to take a naturally antibacterial chemistry and produce a nanorough surface with that material. One such study compared the bacterial colonization of nanorough $\mathrm{ZnO}$ particle compacts to $\mathrm{ZnO}$ and titanium surfaces of conventional roughness. ${ }^{37} \mathrm{ZnO}$ nanoparticles (mean average diameter $=23 \mathrm{~nm}$ ) were pressed into compacts via a cold compaction technique to product surfaces with nanoroughness (Figure 4). For comparison, compacts of $\mathrm{ZnO}$ particles with a grain size of $4.1 \mu \mathrm{m}$ were also produced. When $S$. epidermidis were cultured on the material surfaces, a decrease in CFUs was observed on micronrough $\mathrm{ZnO}$ compared to conventional titanium. A $35 \%$ further decrease
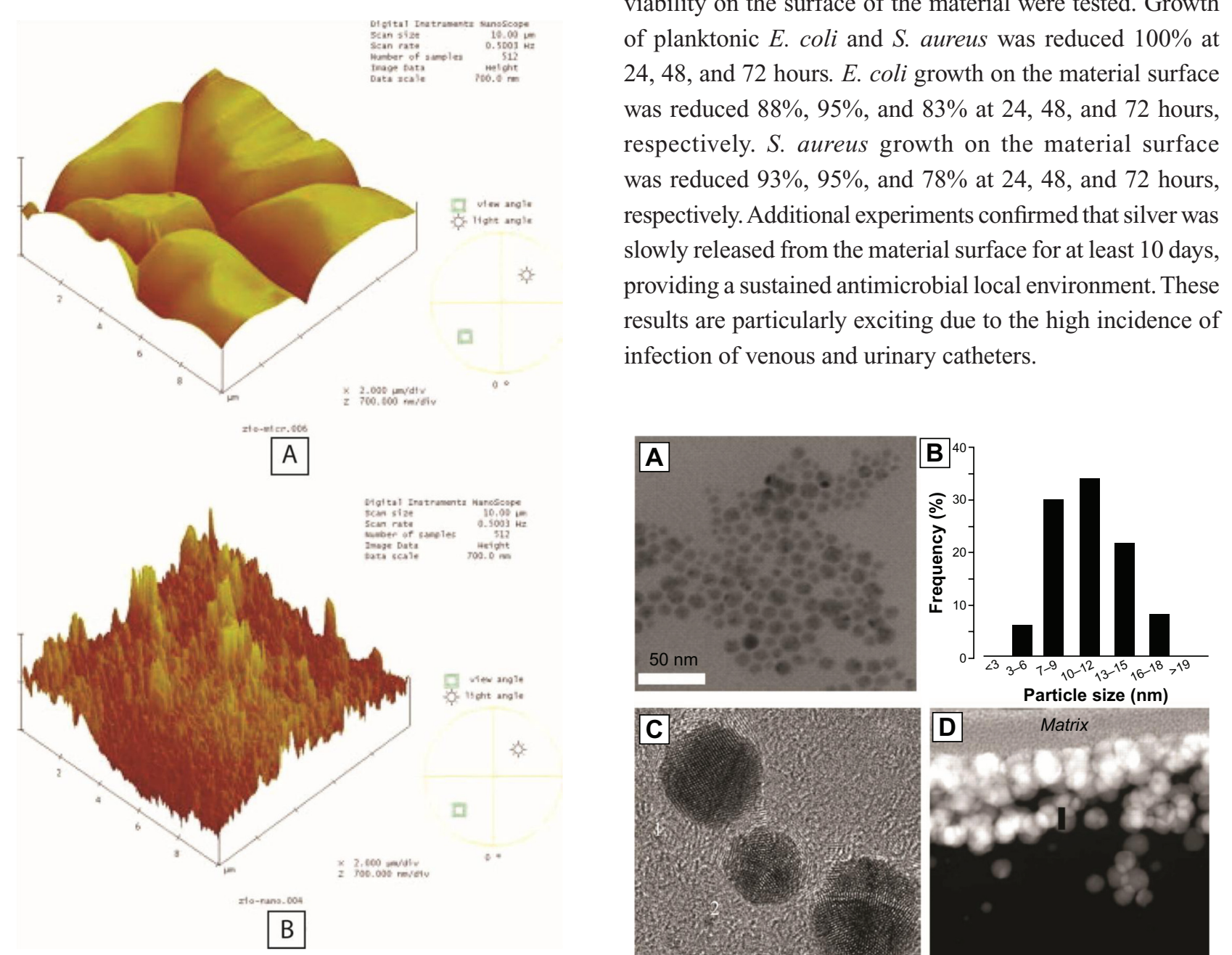

Figure 4 Atomic force microscopy images of particle compacts of microphase zinc oxide $(\mathrm{ZnO})(\mathbf{A})$ and nanophase $\mathrm{ZnO}(\mathbf{B})$. Analysis indicated that compacts of nanophase $\mathrm{ZnO}$ had a $25 \%$ increase in surface area. Copyright (C) 2006, John Wiley and Sons. Adapted with permission from Colón G, Ward BC, Webster TJ. Increased osteoblast and decreased Staphylococcus epidermidis functions on nanophase $\mathrm{ZnO}$ and TiO2. J Biomed Mater Res A. 2006;78(3):595-604. ${ }^{7}$ in $\mathrm{CFU} / \mathrm{cm}^{2}$ was observed on nanorough $\mathrm{ZnO}$ compared to micronrough $\mathrm{ZnO}$. The antibacterial effect of zinc ions has been established, as has the enhanced release of metal ions from grain boundaries of nanomaterials. This explains one element of the mechanism of reduced bacteria activity on nanorough $\mathrm{ZnO}$. Additionally, the nanoroughness of the surface may have played in a role in reducing bacteria adhesion.

Traditional biomaterial surfaces can also be functionalized with antimicrobial nanoparticles to produce a surface resistant to biofouling. In one such study, the polymer surface of a catheter was coated with silver nanoparticles (mean average diameter $=10 \mathrm{~nm}) .{ }^{38}$ Multiple layers of nanoparticles were coated on the material surface to provide a layer with a thickness of 80-120 nm (Figure 5). Pieces of the functionalized catheter were placed in a bacteria cell suspension for up to 72 hours. The growth of bacteria in culture media and the viability on the surface of the material were tested. Growth of planktonic E. coli and S. aureus was reduced $100 \%$ at 24, 48, and 72 hours. E. coli growth on the material surface was reduced $88 \%, 95 \%$, and $83 \%$ at 24,48 , and 72 hours, respectively. $S$. aureus growth on the material surface was reduced $93 \%, 95 \%$, and $78 \%$ at 24,48 , and 72 hours, respectively. Additional experiments confirmed that silver was slowly released from the material surface for at least 10 days, providing a sustained antimicrobial local environment. These infection of venous and urinary catheters.
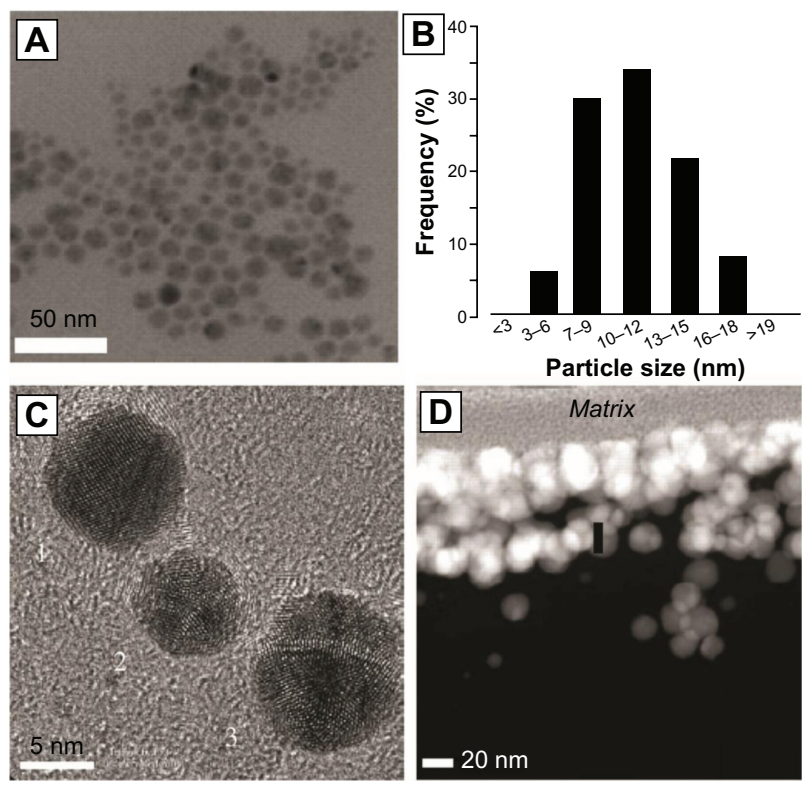

Figure 5 X-ray electron microscopy image of silver nanoparticles (A) and a particle size distribution histogram (B) of those particles. Higher magnification reveals polyhedral structure (C). Nondisruptive electron transmission microscopy reveals an 80-120 nm coating of silver nanoparticles on the surfaces of a polymer catheter (D). 


\section{Conclusion}

Due to the increasing ineffectiveness of traditional antibiotics, the nanoparticle has received increasing attention for its potential antimicrobial effects and applications. This makes the potential to treat infection with nanoparticles very intriguing. In vitro studies have identified nanoparticle concentrations which inhibit a variety of bacteria species. Nanoparticles of different materials and of different sizes vary in their effectiveness. The magnitude of the bactericidal/ bacteriostatic effect of the nanoparticle determines the dose required to effectively inhibit bacteria activity.

$\mathrm{ZnO}$ and silver nanoparticles, in particular, provide a substantial reduction in bacteria viability. A review of previous studies reveals that particle diameter and surface charge are among the most relevant parameters which determine the effectiveness of an antimicrobial nanoparticle. In each study reviewed, the smallest nanoparticle tested generally had the strongest bactericidal effect. An increasingly positive surface charge (which results in the nanoparticle being drawn to the negatively-charged surface of the bacteria) is another property that enhanced bactericidal effects. While other nanoparticle chemistries, such as iron oxide, exhibit a lesser antibacterial effect, they may be functionalized with antimicrobial agents and directed with a magnetic field to provide custom, targeted infection treatments. Toxicity of nanoparticles to eukaryotic cells is a legitimate concern but may be addressed by targeting nanoparticles to a specific site and confining cytotoxic nanoparticle concentrations to the local environment of an infection.

Future studies will observe more physiologically relevant modes of bacteria introduction to and interaction with nanomaterials. In vitro studies often use liquid suspensions of bacteria in culture media that quickly develop into bacteria populations which are far greater than physiologically relevant values. To better understand the ability of nanoparticles and nanomaterial surfaces to prevent or treat infection, animal models of infection are necessary. In this way, the clinical potential of antimicrobial nanoparticles can more accurately be determined.

\section{Disclosure}

The authors report no conflicts of interest in this work.

\section{References}

1. Kallen AJ, Mu Y, Bulens S, et al. Health care - associated invasive MRSA infections, 2005-2008. JAMA. 2010;304(6):641-648.

2. Jones N, Ray B, Ranjit KT, Manna AC. Antibacterial activity of ZnO nanoparticle suspensions on a broad spectrum of microorganisms. FEMS Microbiol Lett. 2008;279(1):71-76.
3. Sondi I, Salopek-Sondi B. Silver nanoparticles as antimicrobial agent: a case study on E. coli as a model for Gram-negative bacteria. J Colloid Interf Sci. 2004;275(1):177-182.

4. Sonak S, Bhosle NB. A simple method to assess bacterial attachment to surfaces. Biofouling. 1995;9:31-38.

5. Söderberg TA, Sunzel B, Holm S, Elmros T, Hallmans G, Sjöberg S. Antibacterial effect of zinc oxide in vitro. Scand J Plast Reconstr Surg Hand Surg. 1990;24(3):193-197.

6. Yamamoto O. Influence of particle size on the antibacterial activity of zinc oxide. Int J Inorg Mater. 2001;3(7):643-646.

7. Dodd AC, McKinley AJ, Saunders M, Tsuzuki T. Effect of particle size on the photocatalytic activity of nanoparticulate zinc oxide. J Nanopart Res. 2006;8(1):43-51.

8. Zhang L, Jiang Y, Ding Y, Povey M, York D. Investigation into the antibacterial behaviour of suspensions of $\mathrm{ZnO}$ nanoparticles $(\mathrm{ZnO}$ nanofluids). J Nanopart Res. 2007;9(3):479-489.

9. Jiang W, Mashayekhi H, Xing B. Bacterial toxicity comparison between nano- and micro-scaled oxide particles. Environ Pollut. 2009;157(5):1619-1625.

10. Reddy KM, Feris K, Bell J, Wingett DG, Hanley C, Punnoose A. Selective toxicity of zinc oxide nanoparticles to prokaryotic and eukaryotic systems. Appl Phys Lett. 2007;90(213902):2139021-2139023.

11. Nair S, Sasidharan A, Divya Rani VV, et al. Role of size scale of $\mathrm{ZnO}$ nanoparticles and microparticles on toxicity toward bacteria and osteoblast cancer cells. J Mater Sci Mater Med. 2009;20 Suppl 1: S235-S241.

12. Padmavathy N, Vijayaraghavan R. Enhanced bioactivity of $\mathrm{ZnO}$ nanoparticles - an antimicrobial study. Sci Technol Adv Mat. 2008; 9(3):35004-35010

13. McCarthy TJ, Zeelie JJ, Krause DJ. The antimicrobial action of zinc ion/antioxidant combinations. J Clin Pharm Ther. 1992;17(1):51-54.

14. Zeelie JJ, McCarthy TJ. Effects of copper and zinc ions on the germicidal properties of two popular pharmaceutical antiseptic agents cetylpyridinium chloride and povidone-iodine. Analyst. 1998;123(3): 503-507.

15. Sawai J, Kawada E, Kanou F, et al. Detection of active oxygen generated from ceramic powders having antibacterial activity. J Chem Eng Jpn. 1996;29(4):627-633.

16. Phan TN, Buckner T, Sheng J, Baldeck JD, Marquis RE. Physiologic actions of zinc related to inhibition of acid and alkali production by oral streptococci in suspensions and biofilms. Oral Microbiol Immunol. 2004;19(1):31-38.

17. Dimkpa CO, Calder A, Britt DW, McLean JE, Anderson AJ. Responses of a soil bacterium, Pseudomonas chlororaphis O6 to commercial metal oxide nanoparticles compared with responses to metal ions. Environ Pollut. 2011;159(7):1749-1756.

18. Morones JR, Elechiguerra JL, Camacho A, et al. The bactericidal effect of silver nanoparticles. Nanotechnology. 2005;16(10):2346-2353.

19. Feng QL, Wu J, Chen GQ, Cui FZ, Kim TN, Kim JO. A mechanistic study of the antibacterial effect of silver ions on Escherichia coli and Staphylococcus aureus. J Biomed Mater Res. 2000;52(4): 662-668.

20. Pal S, Tak YK, Song JM. Does the antibacterial activity of silver nanoparticles depend on the shape of the nanoparticle? A study of the Gram-negative bacterium Escherichia coli. Appl Environ Microbiol. 2007;73(6):1712-1720.

21. Kim JS, Kuk E, Yu KN, et al. Antimicrobial effects of silver nanoparticles. Nanomedicine. 2007;3(1):95-101.

22. Yoon KY, Hoon Byeon J, Park JH, Hwang J. Susceptibility constants of Escherichia coli and Bacillus subtilis to silver and copper nanoparticles. Sci Total Environ. 2007;373(2-3):572-575.

23. Ruparelia JP, Chatterjee AK, Duttagupta SP, Mukherji S. Strain specificity in antimicrobial activity of silver and copper nanoparticles. Acta Biomater. 2008;4(3):707-716.

24. Tran N, Mir A, Mallik D, Sinha A, Nayar A, Webster TJ. Bactericidal effect of iron oxide nanoparticles on Staphylococcus aureus. Int J Nanomedicine. 2010;5:277-283. 
25. Taylor EN, Webster TJ. The use of superparamagnetic nanoparticles for prosthetic biofilm prevention. Int J Nanomedicine. 2009;4:145-152.

26. Simon-Deckers A, Loo S, Mayne-L'hermite M, et al. Size-, composition- and shape-dependent toxicological impact of metal oxide nanoparticles and carbon nanotubes toward bacteria. Environ Sci Technol. 2009;43(21):8423-8429.

27. Qi L, Xu Z, Jiang X, Hu C, Zou X. Preparation and antibacterial activity of chitosan nanoparticles. Carbohydr Res. 2004;339(16):2693-2700.

28. Larsen MU, Seward M, Tripathi A, Shapley NC. Biocompatible nanoparticles trigger rapid bacteria clustering. Biotechnol Prog. 2009; 25(4):1094-1102.

29. Liu S, Wei L, Hao L, et al. Sharper and faster "nano darts" kill more bacteria: a study of antibacterial activity of individually dispersed pristine single-walled carbon nanotube. ACS Nano. 2009;3(12):3891-3902.

30. Jeng HA, Swanson J. Toxicity of metal oxide nanoparticles in mammalian cells. J Environ Sci Health A Tox Hazard Subst Environ Eng. 2006;41(12):2699-2711.

31. Lai JC, Lai MB, Jandhyam S, et al. Exposure to titanium dioxide and other metallic oxide nanoparticles induces cytotoxicity on human neural cells and fibroblasts. Int J Nanomedicine. 2008;3(4):533-545.
32. Karlsson HL, Cronholm P, Gustafsson J, Moller L. Copper oxide nanoparticles are highly toxic: a comparison between metal oxide nanoparticles and carbon nanotubes. Chem Res Toxicol. 2008;21(9): 1726-1732.

33. Brunner TJ, Wick P, Manser P, et al. In vitro cytotoxicity of oxide nanoparticles comparison to asbestos, silica, and the effect of particle solubility. Environ Sci Technol. 2006;40(14):4374-4381.

34. Palmiter RD. Protection against zinc toxicity by metallothionein and zinc transporter 1. Proc Natl Acad Sci U S A. 2004;101(14):4918-4923.

35. Borovansky J, Riley PA. Cytotoxicity of zinc in vitro. Chem Biol Interact 1989;69(2-3):279-291.

36. AshaRani PV, Low Kah Mun G, Hande MP, Valiyaveettil S. Cytotoxicity and genotoxicity of silver nanoparticles in human cells. ACS Nano. 2009;3(2):279-290.

37. Colón G, Ward BC, Webster TJ. Increased osteoblast and decreased Staphylococcus epidermidis functions on nanophase $\mathrm{ZnO}$ and $\mathrm{TiO}_{2}$. J Biomed Mater Res A. 2006;78(3):595-604.

38. Roe D, Karandikar B, Bonn-Savage N, Gibbins B, Roullet JB Antimicrobial surface functionalization of plastic catheters by silver nanoparticles. J Antimicrob Chemother. 2008;61(4):869-876.
International Journal of Nanomedicine

\section{Publish your work in this journal}

The International Journal of Nanomedicine is an international, peerreviewed journal focusing on the application of nanotechnology in diagnostics, therapeutics, and drug delivery systems throughou the biomedical field. This journal is indexed on PubMed Central,

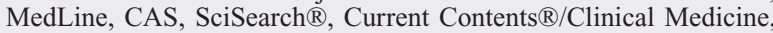

\section{Dovepress}

Journal Citation Reports/Science Edition, EMBase, Scopus and the Elsevier Bibliographic databases. The manuscript management system is completely online and includes a very quick and fair peer-review system, which is all easy to use. Visit http://www.dovepress.com/ testimonials.php to read real quotes from published authors. 